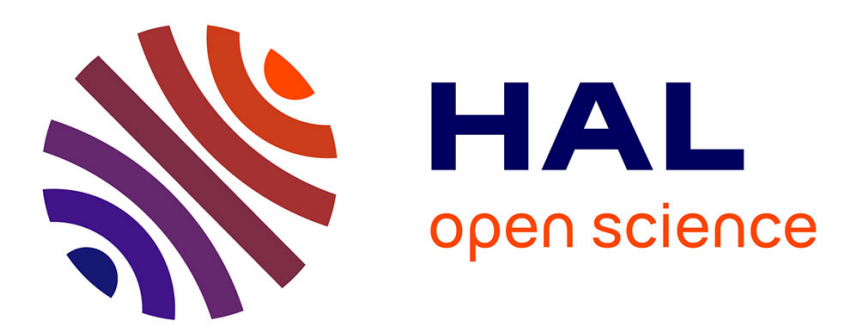

\title{
(IM-)MATERIAL FLOW ANALYSIS FRAMEWORK IMPLEMENTATION ON REPAIR AND REUSE INITIATIVES
}

Julie Gobert, Romain Allais

\section{- To cite this version:}

Julie Gobert, Romain Allais. (IM-)MATERIAL FLOW ANALYSIS FRAMEWORK IMPLEMENTATION ON REPAIR AND REUSE INITIATIVES. Matériaux \& Techniques, 2021, 108 (5-6), 10.1051/mattech/2021012 . hal-03208899

\section{HAL Id: hal-03208899}

https://hal-enpc.archives-ouvertes.fr/hal-03208899

Submitted on 26 Apr 2021

HAL is a multi-disciplinary open access archive for the deposit and dissemination of scientific research documents, whether they are published or not. The documents may come from teaching and research institutions in France or abroad, or from public or private research centers.
L'archive ouverte pluridisciplinaire HAL, est destinée au dépôt et à la diffusion de documents scientifiques de niveau recherche, publiés ou non, émanant des établissements d'enseignement et de recherche français ou étrangers, des laboratoires publics ou privés. 


\title{
(IM-)MATERIAL FLOW ANALYSIS FRAMEWORK IMPLEMENTATION ON REPAIR AND REUSE INITIATIVES
}

\author{
Julie Gobert \\ ENPC, julie.gobert@enpc.fr \\ Romain Allais \\ Apesa, romain.allais@apesa.fr
}

\begin{abstract}
This research aims at understanding better the nature of stakeholders' resistance to and interest in repair and reuse. In fact, the authors assume that in the future waste management could be less centralized using a network of territorialized initiatives based on repair and reuse activities with high social and environmental values.

Such system innovation requires tools and methods to support analysis and facilitate decision-making in multi-stakeholders, multi-scales systems. The framework for spatiotemporal analysis of territorial projects considers a project's stakeholder network and the way they mobilize resources. These resources may be tangible or intangible, brought by individuals, organizations or even the territory.

This communication focuses on the implementation of such an analysis in the community of communes Coeur de Savoie, to understand how local initiatives emerge and on which interactions and resources they are based. This paper proposes feedback on the implementation of the spatio-temporal analysis in one case study (Coeur de Savoie), and provides insights to build new networks promoting reuse and repair.
\end{abstract}

Keywords: repair and reuse initiatives, material and immaterial resources, circular economy, case study 


\section{INTRODUCTION}

A variety of different institutional initiatives have recently emerged in France in line with the European directives (e.g. EU Circular Economy Action Plan (European Commission 2020) and seeking to go beyond simple recycling strategies. Some are promoting circular economy ${ }^{1}$ such as the Energy Transition for Green Growth Act $(2015)^{2}$ or the Anti-Waste Law for a Circular Economy $(2020)^{3}$. As an illustration, rules for furniture waste specify that it is appropriate to "encourage the re-use of elements whose functional and sanitary status is satisfactory or the reuse of waste of furniture." (ADEME et IFOP 2014). This illustrates the growing interest of EU and French institutions in re-employment or re-use through repair.

In addition to this top-down approach, numerous local and national initiatives from the associative sector or the Social and Solidarity Economy ${ }^{4}$ (SSE) are being tested and implemented. These grassroots initiatives which promote reuse, reemployment and repair have existed for several decades (e.g. the Emmaus network founded in 1949), as pointed by (Horne et Maddrell 2002), (Defalvard et Deniard 2016). The diversity of initiatives using circular economy concepts for social purposes is visible in the French Environmental agency annual report (ADEME 2020; ADEME et Harris Interactive 2020).

Despite the variety of the existing solutions, repair and reuse activities remain limited. The reasons for this lack of interest are multiple. First, the lack of 'recognition' from institutions and consumers puts a brake on further development. In fact, practices developed by SSE, and particularly by associations promoting re-employment, do not necessarily have a positive image which creates a sense of trust (Schmidt 2015). SSE initiatives (often located far away from the urban centers) suffer from a negative representation (Gregson et Crewe 2003; Gregson, Crewe, et Brooks 2002). Second, path dependencies also contribute to the under-deployment of repair and reuse activities. Currently, waste processing and recycling organization leaves little room or legitimacy for these emerging initiatives (Pacreau 2016). Third, citizens are unaware of the repair and reuse initiatives, and their view of donating objects for repair/reuse is sometimes negative, discouraging some consumers (ADEME et IFOP 2014; Anstett et Ortar 2015; Rumpala 1999). In addition, the consumer's habits "values associated with ownership and accumulation appear to be important development brakes to new forms of economy" (consumerist habitus, developed in particular by (Herbert et Collin-Lachaud 2017).

The project Recyluse questions the collective capacity to build networks of reuse and repair, while taking into account local characteristics, path dependences and technical lock-in. This is action-research to understand these issues better and overcome limitations to deployment of repair and reuse. This project aims to both analyze the nature of the different objections to and the interest in repair and reuse on the one hand, and develop

\footnotetext{
1 "The transition to a circular economy aims to go beyond the linear economic model consisting of extracting, manufacturing, consuming and disposing of, by calling for a sober and responsible consumption of natural resources and primary raw materials as well as, in order of priority, the prevention of the production of waste, in particular through the reuse of products, and, depending on the hierarchy of waste treatment methods, to reuse, recycle or, failing that, recover waste." (Code de l'environnement, article L. 110-1-1)

${ }^{2}$ Law n² 2015-992 17 August 2015 relating to the energy transition for green growth.

${ }^{3}$ Law $n^{\circ}$ 2020-105 10 February 2020 relating to the fight against waste and the circular economy

4 "The concept of a social and solidarity economy (SSE) designates a set of companies organized in the form of cooperatives, mutual societies, associations, or foundations, whose internal functioning and activities are based on a principle of solidarity and social utility." (Law $n^{\circ} 2014-85631$ July 2014 relating to Social and Solidarity Economy)
}

$2 / 21$ 
and, on the other hand, try out methods and tools to support project stakeholders develop their solutions. These two aims are approached, firstly, by a territorial diagnosis built on observations, a survey of inhabitants, and semi-directive interviews with waste operators, representatives of recyclers, public authorities, users and non-users. Secondly, the organization of multi-level living labs (i.e. product, workshop and territorial level) for collaborative design involving repair/reuse professionals, elected officials, waste managers, designers and users/citizens. Living labs are not detailed here but further information is developed in (Tyl et Allais 2019).

This article investigates how repair and reuse networks can emerge, how stakeholders can interact for action within a specific perimeter, which resources are most useful to achieve their objectives. For this purpose, we have employed the spatiotemporal analysis framework we developed in previous articles (Allais et Gobert 2016, 2019a, 2019b). This method is briefly described below.

\section{METHODOLOGY AND DATA COLLECTION}

Recyluse relies on two case studies: the Pays Basque intercommunal structures (Communauté d'agglomération) and Coeur de Savoie (communautés de communes), but we have chosen to focus our attention on one territory, Coeur de Savoie. We explain how we collected and analyzed the data.

\section{Case study - COEUR DE SAVOIE}

The community of communes Cœur de Savoie ${ }^{5}$ (CdS) (43 rural and rurban municipalities, 35000 inhabitants) is located at the intersection of three valleys leading respectively to Chambéry, Alberville and Grenoble. CdS was created in 2014 after ten years of cooperation between the four previous communities of communes on the themes of agriculture, tourism and economic development.

CdS has also developed a territorial sustainable development project, confirmed by the attribution of the Positive Energy Territory label (TEPOS) in 2015, then the Positive Energy Territory for Green Growth (TEPCV) in July 2016. These labels valorize CdS policy in terms of renewable energy development and energy efficiency.

\footnotetext{
${ }^{5}$ http://www.observatoire.savoie.equipement-agriculture.gouv.fr/Territoire/territoire.php?ID=4
} 


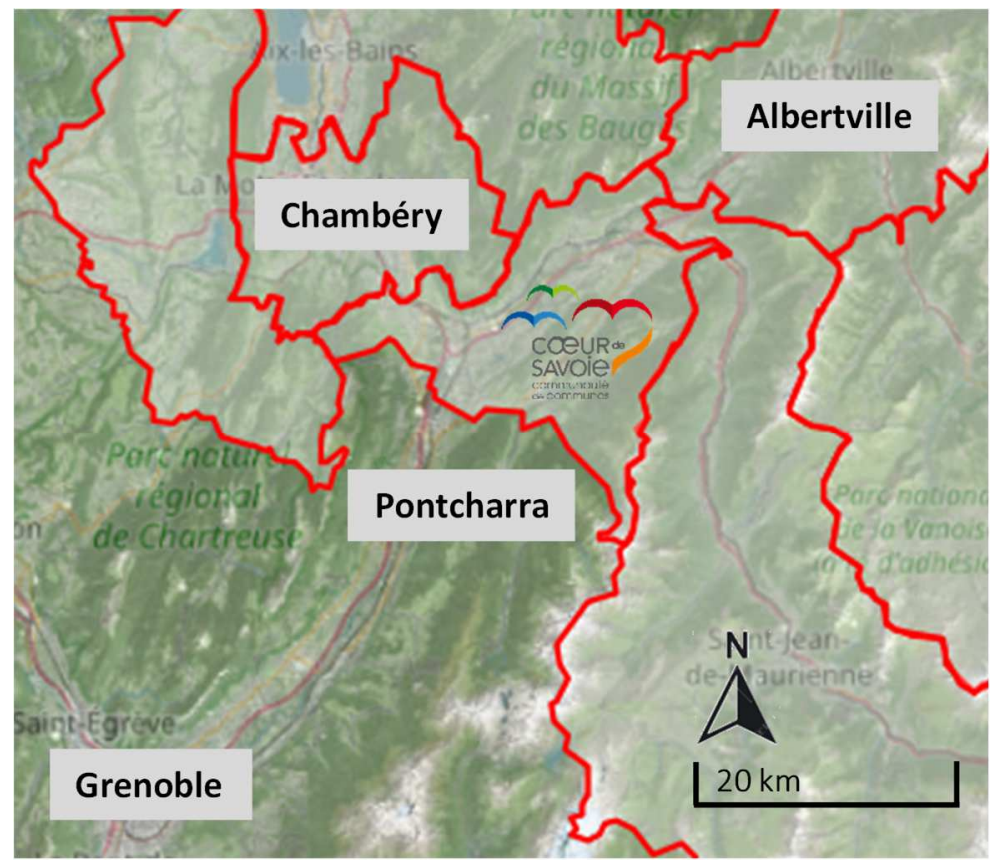

Figure 1- Situation of Coeur de Savoie

The objective of the territorial diagnosis performed on that territory is to determine the socio-genesis of a recyclerie 6 . "A recyclerie is an organization whose vocation is to collect (mainly through direct donations of products or via re-use areas in recycling centers), recover and/or repair, second-hand products or used products (having the status of waste) for resale to the general public. Objects are checked, cleaned and repaired if necessary and feasible (repair, makeover or upcycling). They can also carry out facilitation and environmental awareness missions." (ADEME, 2020).

\section{Data collection}

The territorial diagnosis ${ }^{7}$ was achieved through semi-structured interviews and observations. Interviews with targeted contacts ${ }^{8}$ lasted between ninety minutes to three hours each. Different topics were discussed:

- Definition of the role of the actor in the recyclerie project and his/her relations with the other partners.

- How are the repair and reuse activities integrated into the local environment and more particularly into the local waste management policy?

\footnotetext{
${ }^{6}$ Authors adopt here the French word 'recyclerie' for 'repair and reuse workshops' or 'sorting and recovery center'. They did not found alternative translation. "The term "Ressourcerie $\AA$ " is a trademark registered by the Resourceries Network and to which the structures that wish to adhere to it." (ADEME, 2020)

7 Territorial diagnosis is a common methodology used in social and spatial sciences to better understand the context, resources and human relationships on a specific space (territory). It is particularly employed by spatial planners, consultants in public policies to define the main challenges of the territories and then proposes a plan for actions (Jeannot et al. 2003; Landel et al. 2007). It was here employed to obtain a global view of repairing activities and governance.

${ }^{8}$ Contacts were selected according to their activity (links to waste management or object transformation), as well as by the "snowball effect" (the interviewee was invited to give the name of stakeholders with whom he works for this project).
} 
- Is the project recognized by public, private and public stakeholders?

- What are the obstacles identified by the actors, and how do they intend to solve them?

The interviews were conducted in 2018 and lasted between ninety minutes to three hours each. They were fully recorded, transcribed, coded ${ }^{9}$ and analyzed (Lejeune 2015). This qualitative methodology is based on a very patient reading of the interviews to understand the processes at work, the resources used, and to extract the narrative elaborated by each stakeholder and the possible contradictions between them. The reliability of this process was assured by an in-depth knowledge of the methodology to conceptualize what stakeholders say, independently of the specific place or persons interviewed. (Participant) observation was deployed during meetings we attended or we organized, to look at the relationships ${ }^{9}$ (Peneff 2009; Peretz 2004) and to consolidate the analysis coming from our interviews. These complementary approaches delivered an abundance of qualitative data to understand the spread of repair initiatives, existing issues and the potential institutional or associative ways to solve them.

Interviews were mostly carried out in the interviewees' premises. This createsd the opportunity to combine the interview with a site visit, to appropriate better the places, processes and resources and the way they occupy the space. In fact, this constitutes a major issue for repair/reuse activities (i.e. sales space, storage, waste delivery space, etc.). Each structure adopts its own layout and takes in singular objects rejected by their former owners.

This first task made it possible to determine the organizational and institutional obstacles that the recyclerie project promoters may encounter, to define the resources they mobilize, their expectations of users and non-users.

Interviewed stakeholders are listed in table 1.

\begin{tabular}{|c|c|}
\hline Structure & Function of the interlocutor \\
\hline Companies & Carpenter \& designer (upcycling activity) \\
\hline \multirow{6}{*}{$\begin{array}{l}\text { Structures working in the } \\
\text { waste recovery }\end{array}$} & Co-director - Insertion association \\
\hline & Site director - waste recycling company \\
\hline & Designer and site director - ressourcerie \\
\hline & Director - waste collection company \\
\hline & Director - intercommunal union for household waste \\
\hline & Director - insertion association \\
\hline \multirow{4}{*}{$\begin{array}{l}\text { Public institutions } \\
\text { Community representatives } \\
\text { Elected officials }\end{array}$} & $\begin{array}{l}\text { Mayor and project leader Zero long-term unemployed, former pro- } \\
\text { ject holder of recyclerie }\end{array}$ \\
\hline & Waste service manager - Cœur de Savoie \\
\hline & $\begin{array}{l}\text { Circular economy project manager in charge of the zero waste ter- } \\
\text { ritory initiative - regional agency }\end{array}$ \\
\hline & Business development project manager- regional agency \\
\hline \multirow{4}{*}{ Repair - reuse initiatives } & Recyclerie project holder - La Salamandre \\
\hline & Bike workshop manager \\
\hline & Textile workshop manager \\
\hline & Repair café manager \\
\hline \multirow{2}{*}{ Territorial association } & Director - animation \\
\hline & Member - Restoration and Maintenance Trail paths \\
\hline $\begin{array}{l}\text { Digital tool developers } \\
\text { (not included in the study) }\end{array}$ & $\begin{array}{l}\text { Recyclerie consultant - training for project holders and stc } \\
\text { agement software }\end{array}$ \\
\hline
\end{tabular}

${ }^{9}$ One opening meeting was organized in Coeur de Savoie and workshops in the two case studies to understand the possibilities for overcoming technical, organizational and social issues for activities of repair at the micro, meso and macro-levels. 


\section{Table 1 Interviews conducted at Coeur de Savoie}

The above elements made it possible to carry out the territorial diagnosis thanks to the spatiotemporal analysis framework presented below.

\section{Presentation of the socio-spatial analysis framework for territorial project}

This framework considers socio-spatial and temporal dimensions for project analysis. It examines the pooling of resources during the structuration of networks of actors and the mobilization of territorial resources during projects.

Dynamic network analysis leads to the emergence of the concept of the perimeter for action, an evolving, non-continuous and multi-local innovation space. It is defined by the evolution of the network of actors, their skills and resources, their shared willingness and capacity to influence and concretize the project (Allais et Gobert 2019b).

Resources may be tangible (e.g. wood or machine tools) or intangible (e.g. patent, knowledge), territorial (i.e. specific to a territory), exogenous or generic, but they are all social constructs (Gobert et Allais, 2017). These resources are assessed thanks to the framework for (im-)material flow analysis (Allais et Gobert 2019a) that considers resources at multiple analytical levels, described as micro, meso and macro levels (Gobert et Brullot 2017).

The perimeter for action is dynamic and embedded in a history: both inherited (i.e. previously constructed networks, geographical perimeter, sector ...) or built during the structuring and realization phases of a project as described below.

- Time 0: upstream of the project. Specific local resources, stakeholders, networks that can be mobilized for the project, but are still 'latent', inactivated. These define the initial perimeter for action.

- Time 1: project launch. A need emerges, or one or more stakeholders build a strategy (cf. time 0). They will seek to activate resources, create other relationships to find new partners possessing assets necessary for the launch of the project, such as founders (e.g. government, banks), external expertise (e.g. universities, consulting firms). The perimeter for action will evolve in accordance with the project objective and the input of these new partners.

- Time 2: the project. The activation of territorial resources and the recruitment of the missing external skills (e.g. subcontractors) for the realization of the project will concretize the perimeter for action.

- Time 3: downstream of the project. This is an evolution of time 0: the network developed becomes a latent network that may be activated for a new project, or conversely, in the event of conflict or failure, may be broken up.

The Recyluse project started in January 2018 for a period of two years. The territorial diagnosis was carried out based on data collected mainly during the first year of the project. Consequently, the analysis described below presents only times 0 and 1 of the recyclerie project and not the transition to time 2 which occurred after the end of the project.

Appendix 1 describes the application of this framework for the analysis of stakeholders and territorial resources pooling in CdS. This supports the territorial diagnosis and the sociogenesis of the recyclerie project. 


\section{TERRITORIAL DIAGNOSIS OF REPAIR AND REUSE ORGANISATION IN COEUR DE SAVOIE}

We analyzed the data obtained from interviews to identify the evolution of the perimeter for actions, the role and the number of stakeholders and the resources mobilized at the different steps of the project. Each stage of the recyclerie is described below then summarized in tables: project leaders are identified in the first column, the main incentives to action are described in orange, the main actions carried out are in black and the main causes of the failure of the stage in red.

\section{Time 0: Questioning the waste management system}

Coeur de Savoie is a new intermunicipal structure. Therefore, the executive board is trying to define coherent and consistent public policies for its new area. However, this spatial change requires time to become effective and create efficient synergies. Moreover, concerning the waste management, this administrative area inherits a specific configuration from the past, which can hamper projects promoting repair and reuse.

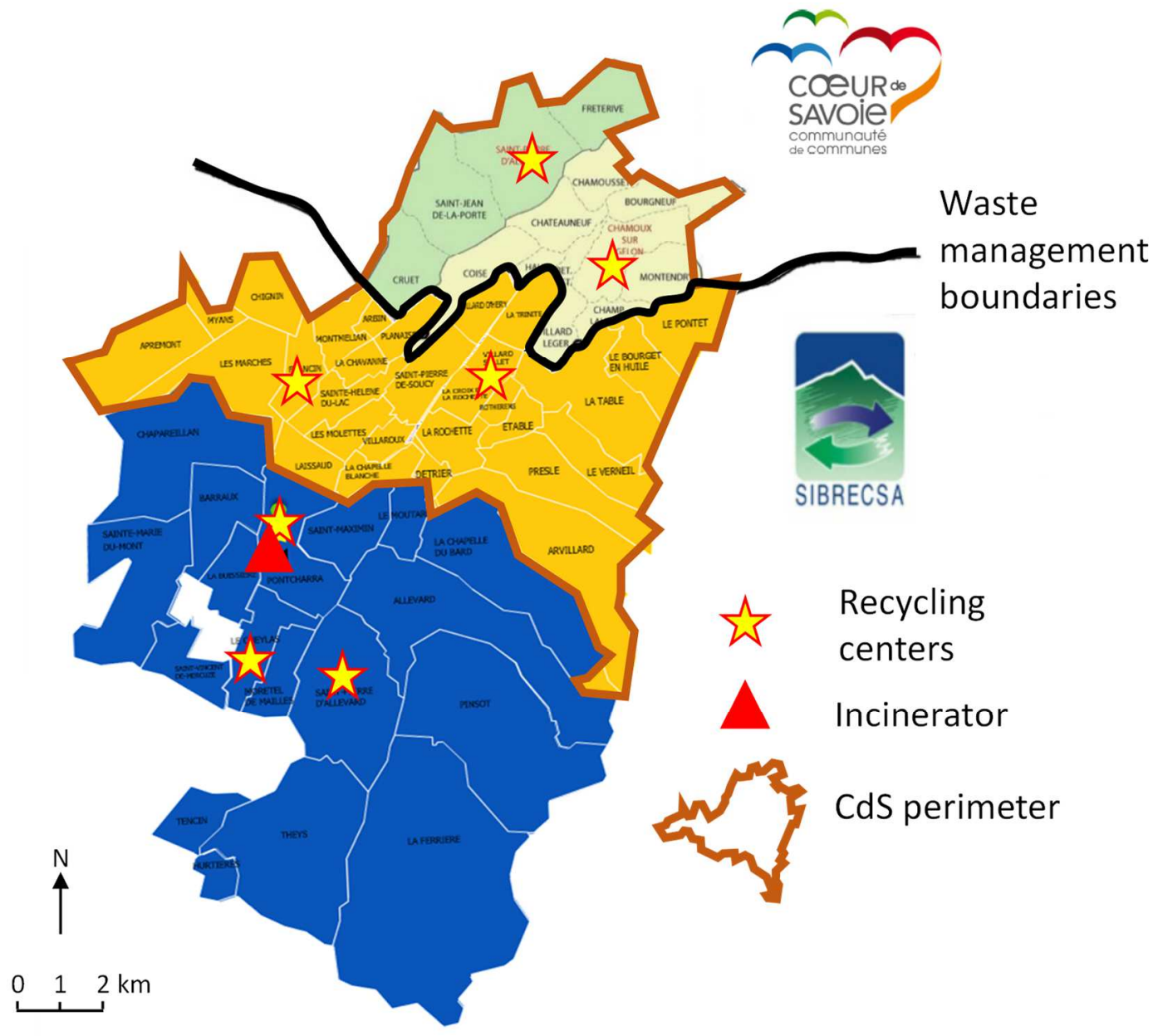

Figure 2 - Waste management of the Coeur de Savoie community of communes

On the one hand, waste collection and treatment are divided into two areas and managed differently (Fig.3). In the north of the community of communes, Coeur de Savoie directly manages the collection and treatment of waste. In the southern part, a syndicate of municipalities (SIBRECSA), linking some municipalities of CdS as well municipalities of 
the bordering department, performed these tasks. This division creates difficulties harmonizing public policies for waste management, including repair and reuse.

On the other hand, in the area managed by SIBRECSA, an incinerator was built in the 1970's and its renovation was recently financed. Consequently, one of the objectives of the executive board is to make this investment profitable. This creates a technological lockin, which could prevent elected representatives actively encouraging repair and reuse.

Regarding repair and reuse initiatives, some have emerged in CdS:

- a craftsman ${ }^{10}$ who upcycles old wooden furniture has recently set up at Saint-Pierrede-Soucy.

- in 2017 a bicycle self-repair workshop ${ }^{11}$ opened in the main town of CdS (Montmélian). It is part of an association promoting cycling in Savoie, based in Chambery.

- at La Rochette, a project holder, who frequented a large fab lab, La Casemate, in Grenoble (50km from CdS - 16.0000 inhabitants) is trying to create a repair café and fab lab with the support of a local association.

- a few years ago the Régie de Territoire ${ }^{12}$ created a sewing activity from canvas sheeting, advertising and truck tarps waste ${ }^{13}$. Their objective was social and professional integration of female job seekers. They are part of departmental, regional and national networks for administrative and creative collaborations, and they find inspiration and make some of their sales online (upcycling market place).

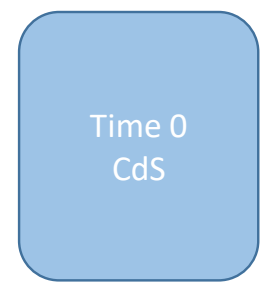

New conurbation defining coherent and consistent public policies on its new area.

$\rightarrow$ Inherited configuration of the waste management system that hamper projects promoting repair and reuse

Some grassroot initiatives on repair and reuse; some scattered initiatives, with little coordinationover the territory that know little or not at all. Influence of structures outside $\mathrm{CdS}$ (fablab in Grenoble, bicycle association from Chambery or online communities)

\section{Time 1: from the emergence to the take-off of a recyclerie project}

\section{Time 1.0: The original idea studied in an associative structure}

Creating a recyclerie was, at the beginning, an idea supported by a local association (régie de territoire), whose ambition was to enable cultural, social and economic development and to create job opportunities for inhabitants (non-competitive activities). The project was inspired by the experience of a mayor of one municipality of CdS, a member of the board of directors of the Régie de Territoire. In fact, he was both a researcher and the president of a Régie de quartier in Grenoble and, in 2003, initiated the creation of a recyclerie in Grenoble. However, regarding the investments in terms of time, human resources

\footnotetext{
10 https://www.api-r-bois.fr/

11 https://rouelibre.net/

12 http://r-fibrethik.fr/ - Associations under the 1901 law, Régies de Quartier and Régies de Territoire are part of a complex alchemy between a solidarity economy, participation of residents and local development to provide concrete responses to the needs of a territory.

13 https://www.atelierfibrethik.com/
} 
and funds, the initial idea was temporally rejected.

Time 1.0

Régie de

territoire $\rightarrow$ Develop a new activity for the Régie de Territoire for integration through economic activity Recyclerie mentioned as a new activity

Abandonment for other activities

\section{Time 1.1: TZCLD, the recyclerie emergence}

This association, in relation with local charities (ADMR and ATD Quart monde), took the opportunity offered by a national call for tenders (Territoire Zéro Chômeur Longue Durée). Local communities were invited to propose new, local solutions for long-term job seekers. The stakeholders created a specific network of associations, citizens, local officials and national institutions (Pole Emploi and la Dirrecte). A dynamic emerged from this brainstorming and the tender writing. The consortium proposed nine development axes (e.g. proximity services development, improving the quality and cleanliness of the living environment or reducing and recovering waste). Amongst the numerous solutions for creating economic activities for long-term job seekers, one suggestion was to develop a recyclerie in the CdS area.

Numerous resources were pooled for writing the tender for the TZCLD project. Initial project holders (charities) collected local data on long-term unemployment while evaluating the potential opportunities of the TZCLD response. CdS supported the project by mandating its management team to participate in the committee's work and visit exemplary national and regional territories. The consortium was finally composed of 22 associations and structures from local, regional and national levels, 63 citizens, including 25 unemployed, and 6 local officials from 27 communes of the community of communes CdS.

The TZCLD project did not get funding and the consortium split up, but some of the participants kept the idea of the recyclerie project alive.

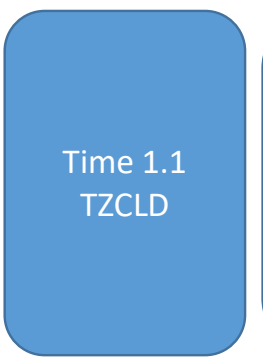

$\rightarrow$ Application for TZCLD experimentation, 6 proposals for creating activities to create local employment (including recycling)

Constitution of a collective (NGOs, citizens, unemployed peoples, industries, community of communes Cœur de Savoie) ; Creation of a common base of knowledge on recyclerie (site visit, inspiration from Villeneuve's recyclerie de Grenoble); Collective definition of the recyclerie concept

Project not selected for the national experiment; Abandonment and dissolution of the collective

\section{Time 1.2.1: La Salamandre}

Based on the TZCLD proposition, a long-term unemployed person (LTUP) took over the responsibility project of recyclerie. In association with CdS and an external consultant, a study of the business model and technical feasibility of La Salamandre, the recyclerie of Coeur de Savoie, was made. The ambition was to create economic activity for eight persons and two technical and administrative managers.

Initially, the LTUP was responsible for both administrative and technical management, followed training given by the ADEME. However, they realized that he was not able to manage these two tasks, lacking time and skills for the administrative part. Help for the administrative management was requested from the director of $R$ de Récup, but there were two issues. First, this person also lacked time to engage in this new project and secondly, the Salamandre is considered as a territorial project. Consequently, it raised administrative difficulties as the DIRRECTE (a deconcentrated service of the state which distributes financial aids for the creation of insertion jobs) works on a specific area (Département). In addition, CdS and the Régie de Territoire were reluctant to give this project to an actor $9 / 21$ 
outside the community of communes.

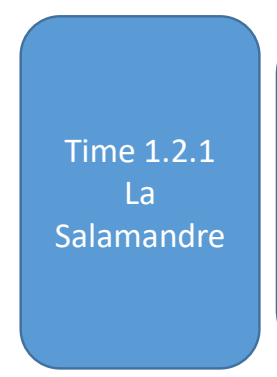

$\rightarrow$ The project's leader's lack of administrative skills, finding suitable premises for the activity Constitution of a small group around the project leader (long-term unemployed involved in the TZCLD project); Technical expertise of the project leader; Inspiration and support from "godfathers" (e.g. Emmaüs in Chambéry); Proposal of administrative management by the director of a recyclerie near but outside the administrative perimeter.

The administrative management was abandoned due to lack of time and the possibility of taking charge by public funders (outside the administrative perimeter)

\section{Time 1.2.2: Recycl'Ethik}

The Régie de Territoire (named Fibr'Ethik) finally employed LTUP and is now managing the recyclerie. The project name is changed to Recycl'ethik, as a part of the Fibr'Ethik activities. A major issue was then the location and the access to a premises of 950 and $1000 \mathrm{~m}^{2}$ for the recyclerie activity and more space for the sewing and gardening activities of the Régie de Territoire. An old industrial building in a commercial area was analyzed but heavy investments were required to fulfil safety standards; the proposition was then rejected. Another opportunity appeared at Saint-Pierre d'Albigny through the creation of a third place with multiple activities in a former industrial site. However, as the business model for this third place became more precise, the area available for the recycling project decreased until the project was no longer feasible. Finally, an old industrial building was found in Saint-Pierre d'Albigny to accommodate all the activities of the Régie de Territoire.

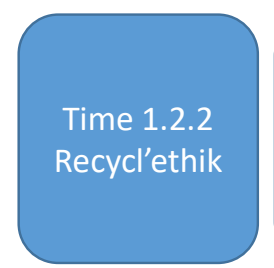

Administrative portage and search for subsidy carried by the régie de territoire which employ the former project older

$\rightarrow$ Difficulty finding premises adapted to the combined constraints of the régie de territoire (relocation of all their activities) and the needs of the recycling plant (large surface area, financing, facilities, etc.)

Recycl'Ethik is scheduled to open in the second quarter of 2020, after the end of the Recyluse project. Consequently, the operational phase of the project (time 2) is not part of this communication.

\section{ANALYSIS OF OUR RESULTS AND DISCUSSION}

Based on the territorial diagnosis, analysis thanks to the spatiotemporal framework highlights arrangements specific to the territory. The multiple stakeholders are listed and presented below, then the network of stakeholders involved in the perimeter for action is described in figure 3 , as a representation of the actors who participated in the different stages of the project's development bringing their specific resources. 


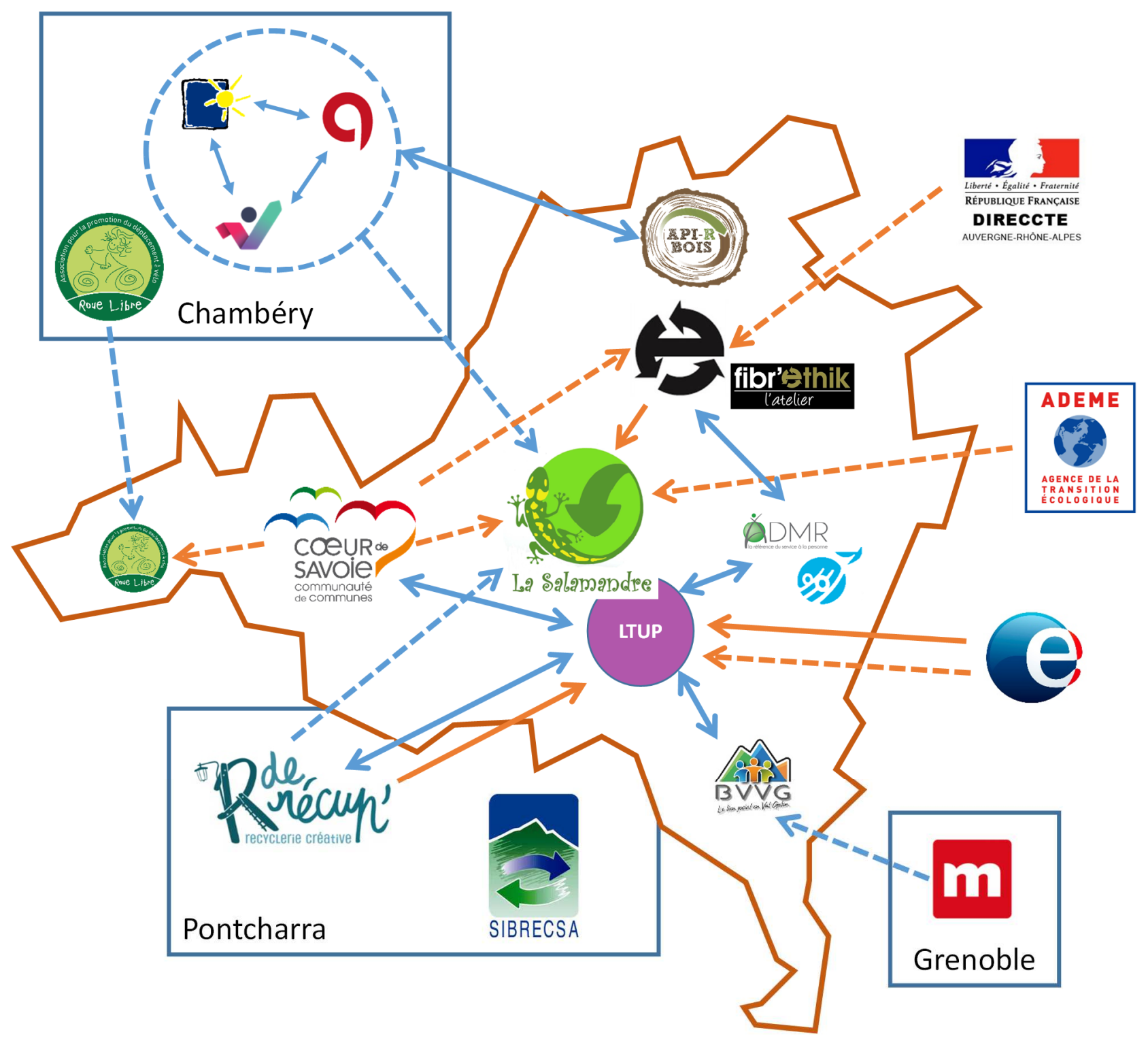

Figure 3 - The internal and external stakeholders involved in the recyclerie project

\section{Analysis}

The analysis of the different interviews does not indicate cooperation between the different reuse and repair initiatives in CdS. Actually, the spatial proximity of these initiatives is not a catalyst for cooperation, as the valleys divide the landscape deeply and lengthen the routes. The perimeter for action of La Salamandre project depends on available premises and the stakeholders' involvement and does not match the area of the inter-municipal organization. The perimeter for action of La Salamandre project does not match the area of the intermunicipal organization, that one part of this, depending of available premises and the stakeholder's involvement. 
Stakeholders committed to the project since Time 1

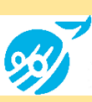

ATD quart monde (local branch of a national association against extreme poverty. At the origin of TZCLD experiment at national level)

äDMR ADMR (local branch of a national associative network of personal services, TZCLD member)

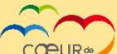

Cour de Savoie (community of communes described in Time 0)
Fibr'ethic (local branch of the CNLRQ national network, association for integration through economic activity and social economy)

Long Term Unemployed Person (job seeker responsible for re-creating a recyclerie, $L a$ Salamandre)

We note that the perimeter for action of the repair reuse initiatives are mainly defined by the affinities and worldviews shared between the actors ${ }^{14}$. Thus, the different initiatives of the territory CdS, consistent with the initiatives of Chambery or Grenoble (e.g. Roue libre implantation in Montmélian or the FabLab at La Rochette), or more distant or digital inspirations for API'R bois or Fibr'Ethik.

Local referrent for the project because they have an experience on the issue

Emmaus (local branch of a national network of shelters for deprived people, historical actor in collection and resale of second-hand goods)

Q TRIALP (social activity to fight against exclusion through economic integration )

L. La Casemate, Fab Lab

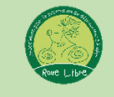
Roue libre Chambéry (association for fixing and promoting bicycles)

Les Chantiers Valoristes (association of social insertion sorting and upcycling waste, trialp and Emmaus Chambery are part of the board)

$\boldsymbol{R}$ de récup, Recyclerie in Pontcharra

Repair reuse initiatives situated outside CdS play a role of referents as they inspire, influence and/or support the local repair and reuse initiatives. Concerning La Salamandre, referents also played a major role in the emergence of the idea, the creation of a common base of knowledge and feedback and providing skills to support the project. In fact, $R$ de récup is a recyclerie in Pontcharra, a city near, but outside CdS intermunicipal organization although located in the SIBRECSA waste management perimeter. It is considered as a model to replicate in the intermunicipal area (inspiration). It also provided both technical skills and insights on the management of a recyclerie. In addition, the development of a self-repair activity was the result of cooperation between a local association promoting cycling mobility and an activist association for cycling in Savoie (Roue Libre), located in Chambery (20km from CdS - 60.000 inhabitants). The Emmaus community, les Chantiers valoristes and Trial ${ }^{15}$ were also referents for CdS stakeholders. These three actors are

${ }^{14}$ In another article (Gobert et Deroubaix 2021), we explain in more detail what we mean from a sociological point of view. Inspiration, worldviews and "orders of values" or cities (Boltanski et Thévenot 2008) play a major role in the possible coordination between actors for this kind of environmental and human-centered activity. Each stakeholder involved in a Recyclerie project would like to make progress in repair and reuse, but different core values motivate them. The worldview of different repair/reuse initiatives and their managers is not the same. They all identify with the world of the project, which promotes commitment, adaptability and they seek to create alternatives to the commercial world structures of consumption and waste through their initiative. The actors position themselves according to the contexts in which they interact with others.

15 Thanks to the revenues earned by reuse and waste management activities, an Emmaus community established since 1970 in Chambery accommodates vulnerable people (homeless, refugees...) and "employs" them for different tasks. Another insertion company, Les Chantiers valoristes, helps persons without employment $12 / 21$ 
particularly close, because they share the same objectives: facilitating the insertion of vulnerable persons, and empowering them, enabling them to develop skills and enabling them step by step to integrate the labor market. The holders of La Salamandre shared this core value as they intended to use waste valorization as a means to valorize people, but had hope for more support from the local public authorities ${ }^{16}$.

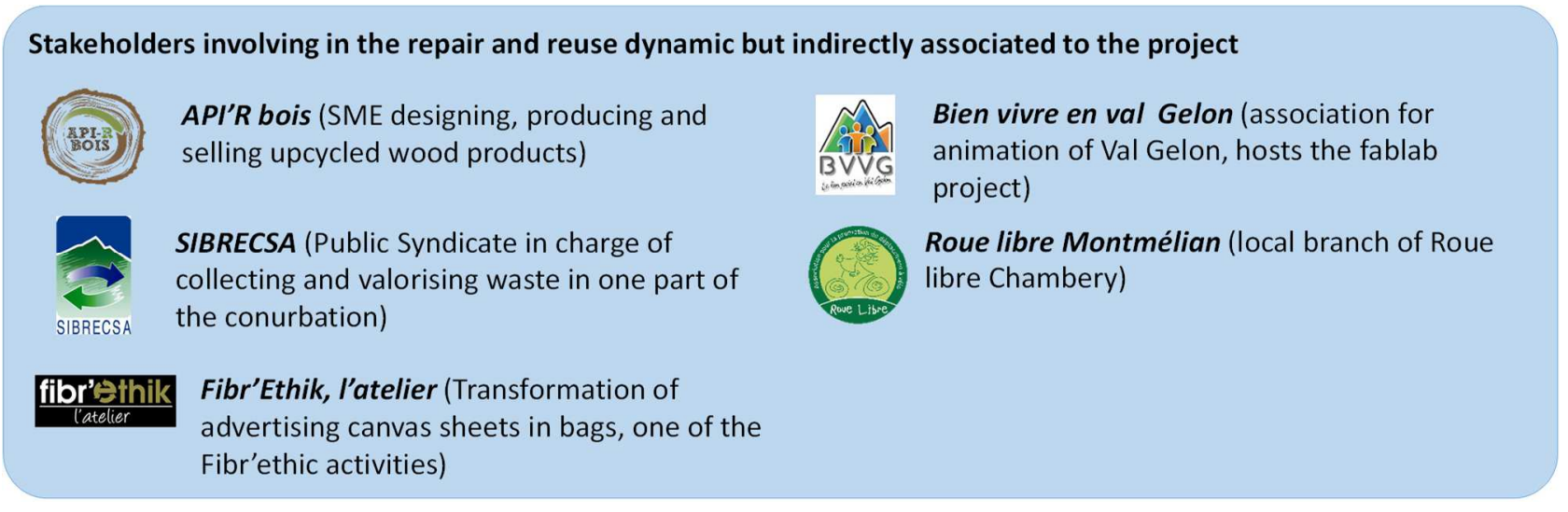

The involvement of the public authorities is both a lever and a liability. The help of the intermunicipal organization was decisive for Roue libre - Montmélian to find their premises, as well for La Salamandre. Generally, the intermunicipal administration displays ambitious objectives to reduce waste flows and enable their transformation. However, its view of repair and reuse workshops is not systematically shared, particularly when the initial impulse comes from the intermunicipal organization ${ }^{17}$. Some national actors (ADEME, POLE EMPLOI or DIRRECTE) provide expertise and fund social jobs or investments.

thanks to economic activities related to the dismantling of products, the recovery and resale of materials, recycling and wood workshops, etc. Trialp is a company collecting and revalorizing waste with the objective of social and professional insertion.

\footnotetext{
16 Numerous project holders consider that society and particularly our ways of consuming, producing and wasting has to be radically reformed. Their main objective is to diminish the human footprint on the environment. Their values correspond to the "civic city" (as they refer to participation, adhesion etc.) and the "inspired city" (creativity). Others are more focused on taking in charge the have-nots without conditions (like Emmaüs) and refer more systematically to solidarity and civic values. Others would rather be part of a legal environment, a collective dynamic and/or do not hesitate to create cooperation with the commercial world. They will seek the support of institutions, particularly local authorities, and take a more institutional approach to ensure the sustainability of their model (Mariasine et Vialleix 2019). These project holders often interact with local and regional authorities that implement local public policies. These authorities can play a role in the territory, particularly in waste prevention policy, and have as a common principle 'the general interest'. They rely on the norm and their capacity to impose decisions, while working for a fair redistribution of rights. These differences can be overcome, but negotiations have to be organized and the core values of each stakeholder must be taken into account.
}

17 As an example, it launched a call for a project to organize a repair café, which was unfruitful, even though some citizens are willing to be committed to this kind of projects. Moreover, as we organized creative workshops with the intermunicipal organization (particularly finding a location, issuing invitations) we felt a silent resistance. 
National institutions

DIRRECTE (State-devolved administration in charge of firms, consumption, work.)

Pole emploi (French administration in charge of unemployed people, provide formations)

ADEME (French Environmental national agency which provides funds for environmental friendly and innovative projects)
La Salamandre, Repair and reuse shop project

Cœur de Savoie boundaires

Material support (premises, waste access)

Methodological or organisational support

Inspiration

Interconnection and/or long-term collaboration

Many actors were involved in this recyclerie project and its successive setbacks, around the definition, as porters or as providers of skills and knowledge. The recyclerie experienced several false starts, but these successive cycles made it possible to move forward and see the emergence of this activity here. The continued support of different actors and continual handing over (from the management to the collective, from the collective to the long-term unemployed then from the long-term unemployed to the management) should be noted. The setbacks were of different natures: doubts about the relevance of carrying out the activity; lack of funding (grants, scope and investments); lack of skills (project engineering) or suitable premises.

\section{Discussion}

\section{Material and immaterial resources essential for repair and reuse activities}

From this case study we can draw a first picture of the resources needed for developing repair and reuse workshops, and maybe territorial networks between initiatives and actors involved in waste management.

To have access to material resources (waste collected in rubbish dumps or directly in retail shops; places/business premises where the different reuse and repair activities can take place), the initiatives often require the help of public actors. These latter are in charge of critical competences like economic development promotion, waste collection and treatment. Public support may have a real positive impact on accelerating the development processes, if the local governments or actors respect the independence and the way of thinking of non-governmental organizations. Mistrust can arise between them. This institutional resource depends on the political dynamics (which motivates the executive board of a community of communes to move forward) and previous experience, which may have already drawn a trajectory and found, activated and mobilized helpful resources.

On the other hand, repair activities cannot be developed without a specific immaterial resource: the skills for project design and management, technical skills for fixing, sewing, etc. The lack of these organizational or technical resources may hamper or stop a project. It was also noticeable that the role of "models" or referents, which can guide the holders while anchoring their project on the territory, are determinant, and can be "employed" or called on at very different times in a project.

\section{Confronting perimeters for action, administrative boundaries and catchment ${ }^{18}$ area}

The mobilization of external, intangible resources (experience in repair and reuse, expertise in waste management etc) shows it is necessity to overcome the territorial limits of

\footnotetext{
18 The catchment area of a business is its geographic area of influence, where the majority of customers come from.
} 
the intercommunal structure.

The perimeter for action evolves in relation to the resources mobilized and the capacity to act and to convince the different stakeholders. In this particular case, recyclerie's holders engage with actors from places outside the CdS territory (Chambery, Grenoble, Pontcharra...), national, regional or departmental networks (e.g. national resourceries network or upcycling networks) or online resources (e.g. online market places). They could glean information, training, advice and expertise. They could also obtain financial support for different elements of their project (funding job creation, investment to transform and adapt technical and commercial premises). The resort to referents is possible because people share common values. Conversely, the recourse to subsidizers, providing financial support, is more pragmatic: depending on calls of tender, opportunities, the initiatives holders' answer and ability to raise money.

In order to facilitate the collaboration between actors, the value system co-construction and the referees' identification are integrated into the living lab tools and methodology and tested in multiple sessions.

The perimeter for action must not be confused either with the catchment area of the recyclerie or the administrative boundaries. La Salamandre's supposed accessibility, and people not requiring a motorized journey, lasting more than $20 \mathrm{~min}$ to reach the recyclerie, define catchment area. The natural landscape that constrains the infrastructures and communications between the two valleys of CdS creates distinct catchment area for R'de recup in one area and Recycl'Ethik in another. The first benefits from the flow of people to Grenoble via the Grésivaudan valley and the second from the flows between Albertville and Chambéry in the Combe de Savoie.

Even if the intercommunal structure Coeur de Savoie was a key actor in the recyclerie development, it was also reluctant to take administrative responsibility outside its borders, which caused a reorientation of the project (cf. time 1.2.1).

\section{CONCLUSION AND FUTURE WORK}

This paper aimed to show research on repair and reuse activities, and some of the results obtained make it possible to understand the resources necessary for building initiatives and networks. Even if there are sometimes some difference in values and misunderstandings between stakeholders, local arrangements can be negotiated progressively.

For the research dimension, this analytical framework made it possible to structure the territorial diagnosis, on the one hand, and to serve as a basis for the development of a serious game deployed within the framework of territorial living labs (Tyl et Allais 2019), on the other.

For project leaders and stakeholders, this framework has no direct utility at this stage. In the long term, it would be possible, by multiplying and crossing the cases, to see bottlenecks emerge on key resources or skills according to the different times in the setting up of a project.

In further articles we will integrate the users' points of view, and endeavor to see how these kinds of local systems of waste valorization can be implemented, and whether they meet the users' expectations, representations and appropriations (Akrich 1998).

This should give insights for decision makers at the local and regional levels, and enable to understand what kinds of new services and systems can be brought in to improve territorial circularities (Schmidt 2015). 


\section{AKNOWLEDGEMENTS}

The authors want to thank the French ecological transition agency (ADEME) for funding the project ( $n^{\circ} 1777 \mathrm{C} 0011$ coordinated by Julie Gobert et José-Frédéric Deroubaix). They also thank interviewees from Coeur de Savoie for their collaboration and support during the project. Benjamin Tyl (APESA) and José-Frédéric Deroubaix (ENPC) are also acknowledged for their participation to this project.

\section{REFERENCES}

ADEME. 2020. Recycleries: des outils au service des territoires. ADEME. https://www.ademe.fr/recycleries-outils-service-territoires (25 février 2021).

ADEME, et Harris Interactive. 2020. Les Français et la réparation : Perceptions et pratiques. www.ademe.fr/mediatheque (7 juin 2020).

ADEME, et IFOP. 2014. Perceptions et pratiques des Français en matière de réemploi des produits. ADEME. https://www.ademe.fr/perceptions-pratiques-francais-matiere-reemploiproduits.

Akrich, Madeleine. 1998. "Les utilisateurs, acteurs de l'innovation ». Education permanente 134: 79-89.

Allais, Romain, et Julie Gobert. 2016. "A multidisciplinary method for sustainability assessment of PSS: Challenges and developments ». CIRP Journal of Manufacturing Science and Technology. https://hal.archives-ouvertes.fr/hal-01537192 (6 juin 2020).

Allais, Romain, et Julie Gobert. 2017. "Environmental assessment of PSS, feedback on 2 years of experimentation ». Matériaux \& Techniques 105(5-6): 504.

Allais, Romain, et Julie Gobert. 2019. "(IM-)Material Flow Analysis for System Innovation » éd. Jean-Pierre Birat et al. Matériaux \& Techniques 107(1): 109.

Anstett, Elisabeth, et Nathalie Ortar. 2015. http://journals.openedition.org/lectures La deuxième vie des objets. Recyclage et récupération dans les sociétés modernes. Pétra (Editions).

Boltanski, Luc, et Laurent Thévenot. 2008. De la justification: les économies de la grandeur. Paris: Gallimard.

Defalvard, Hervé, et Julien Deniard. 2016. "Les organisations de l'économie sociale et solidaire dans l'économie des déchets et du réemploi en Île-de-France : une approche institutionnaliste ». Mouvements 87(3): 69.

European Commission. 2020. Circular Economy Action Plan - For a cleaner and more competitive Europe. https://ec.europa.eu/environment/circular-economy/pdf/new_circular_economy_action_plan.pdf.

Gobert, Julie, et Sabrina Brullot. 2017. «La mobilisation du capital territorial pour le développement d'une logique d'Écologie industrielle et territoriale ". Revue dEconomie Regionale Urbaine Décembre(5): 881-904.

Gobert, Julie, et José-Frédéric Deroubaix. 2021. «Réparer, recoudre, restaurer... Des collectivités locales en tâtonnement ". Géocarrefour 95(95/1). http://journals.openedition.org/geocarrefour/16518 (25 février 2021).

Gregson, Nicky, et Louise Crewe. 2003. Second-Hand Cultures. Oxford: Berg.

Gregson, Nicky, Louise Crewe, et Kate Brooks. 2002. "Discourse, Displacement, and Retail Practice: Some Pointers from the Charity Retail Project ». Environment and Planning A: Economy and Space 34(9): 1661-83.

Herbert, Maud, et Isabelle Collin-Lachaud. 2017. "Pratiques collaboratives et habitus consumériste: une analyse des mécanismes transformatifs de la consommation collaborative ». Recherche et Applications en Marketing (French Edition) 32(1): 42-62.

Horne, Suzanne, et Avril Maddrell. 2002. Charity shops: retailing consumption and society. London; New York: Routledge. 
Jeannot, G., A. Yalha, S. Maujean, et S. Grillet. 2003. Le diagnostic territorial: un outil de l'action publique. CERTU.

Landel, Pierre-Antoine et al. 2007. "Le diagnostic stratégique de territoire ». https://halshs.archives-ouvertes.fr/halshs-00321357 (15 février 2021).

Mariasine, Léo, et Martiane Vialleix. 2019. "Vers une approche métabolique des espaces urbains ». Note rapide Environnement, Institut Paris Région (823): 4.

Pacreau, Fanny. 2016. "La récupération dans les déchèteries : formes, motivations et devenir ». Mouvements 87(3): 96.

Rumpala, Yannick. 1999. "Le réajustement du rôle des populations dans la gestion des déchets ménagers. Du développement des politiques de collecte sélective à l'hétérorégulation de la sphère domestique ». Revue française de science politique 49(4): 601-30.

Schmidt, D. 2015. "Product-Service Systems for Influencing Customer Barriers and Customer Acceptance ". Journal of Economics, Business and Management 3(10). http://www.joebm.com/index.php?m=content\&c=index\&a=show\&catid=51\&id=630 (26 août 2019).

Tyl, Benjamin, et Romain Allais. 2019. « Living labs to develop reuse and repair workshops in territories ». In Berlin. 
Appendix 1 - Stakeholders and territorial resources pooling analysis

\begin{tabular}{|c|c|c|c|c|c|c|c|}
\hline & & & Time 0 & $\begin{array}{l}\text { Time } 1.0 \\
\text { Régie de territoire }\end{array}$ & $\begin{array}{l}\text { Time } 1.1 \\
\text { TZCLD }\end{array}$ & $\begin{array}{l}\text { Time 1.2.1 } \\
\text { La Salamandre }\end{array}$ & $\begin{array}{l}\text { Time } 1.2 .2 \\
\text { La Salamandre }\end{array}$ \\
\hline \multirow{8}{*}{ 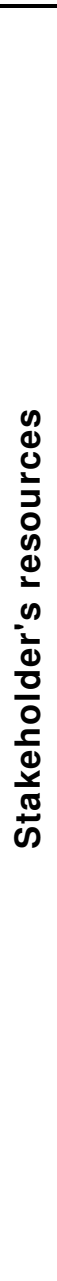 } & $\begin{array}{l}\text { Human } \\
\text { capital }\end{array}$ & $\begin{array}{l}\text { Individual and col- } \\
\text { lective skills of pro- } \\
\text { ject leaders }\end{array}$ & NA & $\begin{array}{l}\text { Ability to lead this } \\
\text { administrative, tech- } \\
\text { nical project }\end{array}$ & $\begin{array}{c}\text { Local Experimentation Commit- } \\
\text { tee composed of multiple profiles } \\
\text { and skills (elected officials and } \\
\text { local authorities, associations, } \\
\text { unemployed people, companies). } \\
\text { Site visit and feedback from Gre- } \\
\text { noble recycling plant }\end{array}$ & $\begin{array}{c}\text { Technical skills, lack of adminis- } \\
\text { trative skills in management of a } \\
\text { structure; HR need assessed for } \\
7 / 8 \text { people in integration (part- } \\
\text { time), } 2 \text { people technical and ad- } \\
\text { ministrative supervision (half- } \\
\text { time) }\end{array}$ & $\begin{array}{l}\text { Salary of the bearer by the } \\
\text { territory management. } \\
\text { Technical supervision by } \\
\text { carrier. Administrative } \\
\text { support and management } \\
\text { provided by the Regional } \\
\text { Board }\end{array}$ \\
\hline & $\begin{array}{l}\text { Brand } \\
\text { capital }\end{array}$ & $\begin{array}{l}\text { Recognition and ac- } \\
\text { ceptance of the } \\
\text { value proposition by } \\
\text { users }\end{array}$ & NA & $\begin{array}{l}\text { Association recog- } \\
\text { nized in the local } \\
\text { socio-economic fab- } \\
\text { ric through its fi- } \\
\text { br'etic offers and } \\
\text { green spaces }\end{array}$ & t & & \\
\hline & $\begin{array}{l}\text { Organiza- } \\
\text { tional } \\
\text { capital }\end{array}$ & $\begin{array}{l}\text { Mastery of the pro- } \\
\text { cesses necessary to } \\
\text { realize the value } \\
\text { proposition }\end{array}$ & NA & $\begin{array}{l}\text { Project mode mas- } \\
\text { tery, research fund- } \\
\text { ing }\end{array}$ & $\begin{array}{l}\text { Mastery of collaborative projects } \\
\text { in large groups }\end{array}$ & $\begin{array}{l}\text { No formal process. Training of- } \\
\text { fered by ADEME on setting up } \\
\text { and managing a recycling plant; } \\
\text { consulting firm support }\end{array}$ & $\begin{array}{l}\text { Integration of the project } \\
\text { leader in the organization } \\
\text { of the Régie de Territoire }\end{array}$ \\
\hline & $\begin{array}{l}\text { Partners } \\
\text { capital }\end{array}$ & $\begin{array}{l}\text { Quality of the rela- } \\
\text { tionship and perfor- } \\
\text { mance of commer- } \\
\text { cial and non-com- } \\
\text { mercial partners }\end{array}$ & NA & $\begin{array}{l}\text { Collaboration with } \\
\text { the town hall of } \\
\text { Saint Pierre d'Al- } \\
\text { bigny (provision of } \\
\text { premises) }\end{array}$ & $\begin{array}{c}\text { Strong collaboration between } \\
\text { partners for the construction of } \\
\text { the TZCLD offer }\end{array}$ & $\begin{array}{c}\text { Collaboration with R'de Recover } \\
\text { on the management of a recy- } \\
\text { cling plant; Relationship with } \\
\text { comcom for access to the re- } \\
\text { source (recycling center) and ad- } \\
\text { ministrative support }\end{array}$ & $\begin{array}{c}\text { Benefits from the anchor- } \\
\text { ing of the structure and its } \\
\text { collaborations with com- } \\
\text { munities (Saint Pierre d'Al- } \\
\text { bigny town hall, CdS } \\
\text { comcom) }\end{array}$ \\
\hline & $\begin{array}{c}\text { Shareholder } \\
\text { / funder } \\
\text { capital }\end{array}$ & $\begin{array}{l}\text { Nature and quality } \\
\text { of funders }\end{array}$ & NA & & $\begin{array}{l}\text { Call for national applications for } \\
\text { TZCLD experimentation }\end{array}$ & Public funding & Public funding \\
\hline & $\begin{array}{l}\text { Information } \\
\text { system } \\
\text { capital }\end{array}$ & $\begin{array}{l}\text { Alignment of the in- } \\
\text { formation system } \\
\text { with user needs }\end{array}$ & NA & NA & NA & $\begin{array}{c}\text { Software solution to manage } \\
\text { flows in the recycling center dur- } \\
\text { ing ademe training; Widely de- } \\
\text { ployed software (including R'de } \\
\text { recover) }\end{array}$ & \\
\hline & $\begin{array}{l}\text { Customer } \\
\text { capital }\end{array}$ & $\begin{array}{c}\text { Alignment of val- } \\
\text { ues, loyalty and sat- } \\
\text { isfaction }\end{array}$ & NA & & & & \\
\hline & $\begin{array}{l}\text { Knowledge } \\
\text { capital }\end{array}$ & $\begin{array}{l}\text { Intelligence in- } \\
\text { corporated into } \\
\text { products (technol- } \\
\text { ogy, patents, R \& D } \\
\text { capacity, etc.) }\end{array}$ & NA & & & $\begin{array}{l}\text { Empirical knowledge of the } \\
\text { project holder on product repair; } \\
\text { No formalization }\end{array}$ & \\
\hline
\end{tabular}




\begin{tabular}{|c|c|c|c|c|c|c|}
\hline $\begin{array}{l}\text { Societal } \\
\text { capital }\end{array}$ & $\begin{array}{l}\text { Intrinsic quality of } \\
\text { the territory (infra- } \\
\text { structure, public } \\
\text { services, employ- } \\
\text { ment pool, public } \\
\text { services, etc.) }\end{array}$ & $\begin{array}{l}\text { Diversi- } \\
\text { fied but } \\
\text { precari- } \\
\text { ous job } \\
\text { offer, }\end{array}$ & $\begin{array}{l}\text { Recycling consid- } \\
\text { ered as an activity } \\
\text { for integration }\end{array}$ & $\begin{array}{c}\text { Employment as a central prob- } \\
\text { lem of the project; recycling as a } \\
\text { solution among others; Mobility } \\
\text { issues addressed in TZCLD dos- } \\
\text { sier }\end{array}$ & $\begin{array}{c}\text { Recycling as a business creation } \\
\text { and insertion }\end{array}$ & $\begin{array}{l}\text { Recycling considered as } \\
\text { an activity for integration }\end{array}$ \\
\hline $\begin{array}{l}\text { Natural } \\
\text { capital }\end{array}$ & $\begin{array}{l}\text { Intrinsic quality of } \\
\text { the space (attrac- } \\
\text { tiveness) and envi- } \\
\text { ronmental risks } \\
\text { (supply, air quality, } \\
\text { water, etc.) }\end{array}$ & $\begin{array}{l}\text { not eval- } \\
\text { uated }\end{array}$ & & & & \\
\hline $\begin{array}{l}\text { Financial } \\
\text { capital }\end{array}$ & Financial capacities & NA & $\begin{array}{l}\text { Dependence on ex- } \\
\text { ternal funding }\end{array}$ & $\begin{array}{c}\text { No existing budget. Dependence } \\
\text { on external funding (community } \\
\text { of municipalities, department, } \\
\text { state and Europe) }\end{array}$ & $\begin{array}{l}\text { Financial insecurity (Long-term } \\
\text { unemployed) recycling as a busi- } \\
\text { ness creation. }\end{array}$ & $\begin{array}{l}\text { Dependence on external } \\
\text { funding }\end{array}$ \\
\hline $\begin{array}{l}\text { Tangible } \\
\text { capital }\end{array}$ & $\begin{array}{l}\text { Equipment and in- } \\
\text { frastructure }\end{array}$ & NA & $\begin{array}{c}\text { Premises made } \\
\text { available at the } \\
\text { town hall but space } \\
\text { saturated with sew- } \\
\text { ing activities and } \\
\text { green space; end of } \\
\text { lease } \\
\end{array}$ & $\begin{array}{l}\text { Meeting places provided by } \\
\text { comcom }\end{array}$ & $\begin{array}{l}\text { Problem: find premises suitable } \\
\text { for the activity }\end{array}$ & $\begin{array}{l}\text { Problem: find premises } \\
\text { suitable for recycling and } \\
\text { Fibr'etik activities }\end{array}$ \\
\hline
\end{tabular}




\begin{tabular}{|c|c|c|c|c|c|c|c|}
\hline & & & Time 0 & $\begin{array}{c}\text { Time } 1.0 \\
\text { Régie de territoire }\end{array}$ & $\begin{array}{c}\text { Time } 1.1 \\
\text { TZCLD } \\
\end{array}$ & $\begin{array}{c}\text { Time } 1.2 .1 \\
\text { La Salamandre } \\
\end{array}$ & $\begin{array}{c}\text { Time } 1.2 .2 \\
\text { La Salamandre } \\
\end{array}$ \\
\hline \multirow{12}{*}{ 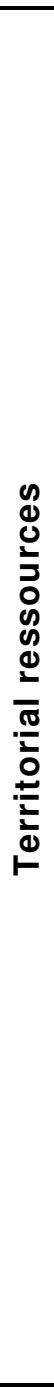 } & \multirow{4}{*}{$\begin{array}{l}\text { Organiza- } \\
\text { tional re- } \\
\text { source }\end{array}$} & $\begin{array}{l}\text { Power rela- } \\
\text { tionships }\end{array}$ & & \multirow{12}{*}{$\begin{array}{l}\text { No particular resources } \\
\text { were employed or neces- } \\
\text { sary because Regie de } \\
\text { territoire's executive } \\
\text { board decided to focus on } \\
\text { different activities }\end{array}$} & $\begin{array}{l}\text { Local dynamics for TZCLD: } \\
\text { creation of a community for } \\
\text { project }\end{array}$ & $\begin{array}{l}\text { CDS tries to impose the vision of the } \\
\text { public authority. }\end{array}$ & \\
\hline & & $\begin{array}{l}\text { Informal rela- } \\
\text { tions }\end{array}$ & & & & $\begin{array}{l}\text { Relations with other charities located } \\
\text { in nearby territories }\end{array}$ & \\
\hline & & $\begin{array}{c}\text { Trust be- } \\
\text { tween actors }\end{array}$ & $\begin{array}{l}\text { Associative organi- } \\
\text { zation network }\end{array}$ & & & & \\
\hline & & $\begin{array}{l}\text { Grassroots } \\
\text { organiza- } \\
\text { tions } \\
\text { (associa- } \\
\text { tions, clubs) }\end{array}$ & $\begin{array}{l}\text { Insertion and chari- } \\
\text { table associations }\end{array}$ & & $\begin{array}{c}\text { Insertion and caritative as- } \\
\text { sociations }\end{array}$ & $\begin{array}{l}\text { Insertion and caritative associations } \\
\text { are less involved into the project: they } \\
\text { want Salamandre leader to transform } \\
\text { the initial idea into something real } \\
\text { and to develop the territorial network }\end{array}$ & \\
\hline & \multirow{5}{*}{$\begin{array}{l}\text { Cognitive } \\
\text { and tech- } \\
\text { nical } \\
\text { resources }\end{array}$} & $\begin{array}{l}\text { Local history } \\
\text { (common ex- } \\
\text { periences...) }\end{array}$ & & & & & \\
\hline & & $\begin{array}{l}\text { Values shar- } \\
\text { ing }\end{array}$ & & & $\begin{array}{c}\text { Finding a new way to em- } \\
\text { ploy job seekers is the main } \\
\text { objective of the stakehold- } \\
\text { ers }\end{array}$ & & \\
\hline & & Know-how & $\begin{array}{l}\text { An associative } \\
\text { stakeholder }=\text { an- } \\
\text { cient researcher }\end{array}$ & & $\begin{array}{l}\text { Administrative skills (com- } \\
\text { munity of communes), so- } \\
\text { cial knowledge developed } \\
\text { by the charities }\end{array}$ & & \\
\hline & & Skills & $\begin{array}{l}\text { Upcycling technical } \\
\text { skills: Api'r Bois, } \\
\text { Régie de Territoire, }\end{array}$ & & & $\begin{array}{l}\text { Experience exchange with charities } \\
\text { located in other areas, and more spe- } \\
\text { cifically with a new recyclerie }\end{array}$ & \\
\hline & & $\begin{array}{l}\text { Research in- } \\
\text { stitutions, } \\
\text { schools }\end{array}$ & & & & & \\
\hline & \multirow[t]{2}{*}{$\begin{array}{l}\text { Natural } \\
\text { resources }\end{array}$} & Landscape & $\begin{array}{l}\text { Constraints imposed } \\
\text { by a mountain area } \\
\text { (a very relative geo- } \\
\text { graphical proximity) }\end{array}$ & & & & \\
\hline & & $\begin{array}{c}\text { Natural } \\
\text { resources }\end{array}$ & & & & & \\
\hline & $\begin{array}{l}\text { Institu- } \\
\text { tional } \\
\text { resources }\end{array}$ & $\begin{array}{l}\text { Involved } \\
\text { public au- } \\
\text { thorities }\end{array}$ & $\begin{array}{l}\text { Community of com- } \\
\text { munes Cœur de Sa- } \\
\text { voie }\end{array}$ & & $\begin{array}{l}\text { Community of communes } \\
\text { Cœur de Savoie and partic- } \\
\text { ularly the sector and the } \\
\text { elected representative in } \\
\text { charge of sustainability }\end{array}$ & ADEME (with specific formations) & $\begin{array}{l}\text { CdS : Support for } \\
\text { the quest for } \\
\text { premises and the } \\
\text { organization of } \\
\text { meetings }\end{array}$ \\
\hline
\end{tabular}




\begin{tabular}{|c|c|c|c|}
\hline & $\begin{array}{l}\text { Norms and } \\
\text { customs }\end{array}$ & $\begin{array}{l}\text { Waste management } \\
\text { regulation }\end{array}$ & $\begin{array}{l}\text { The institutional interest was growing } \\
\text { concerning repair and reuse initia- } \\
\text { tives: a legislative text was studying } \\
\text { in the Parliament }\end{array}$ \\
\hline $\begin{array}{l}\text { Infrastruc- } \\
\text { tural re- } \\
\text { sources }\end{array}$ & $\begin{array}{c}\text { Infrastruc- } \\
\text { ture }\end{array}$ & $\begin{array}{l}\text { Sibrecsa-incinerator } \\
\text { (path dependency) }\end{array}$ & \\
\hline
\end{tabular}

